\title{
LAND GOVERNANCE AND LAND DEALS IN AFRICA: OPPORTUNITIES AND CHALLENGES IN ADVANCING COMMUNITY RIGHTS
}

\author{
Blair Rutherford*
}

\begin{abstract}
This article examines the converging focus on "governance" by those donors and scholars who promote investment in land in Africa as well as by scholars and activists who criticize what they call "land grabs." This focus on governance is particularly found in terms of understanding and assessing socio-economic consequences among the communities for the land deals, investment initiatives which have been accelerating on the continent over the last decade and longer. This article expands the concept of governance by examining how structures of authority and power are also involved in defining who belongs, or who has claims to belong, to these territories. It explores the topic of land deals and community rights through the conceptual lens of governance and belonging, the ability to be recognized as part of the community at various levels of action (including in terms of national citizenship). It starts with an examination of the recent increase in land investments in Africa, setting out its broad parameters, including public criticisms raised and some of the protests around them, and noting some of the key issues on which scholars have focused. In the next two sections, the article analyses these processes through the conceptual lens of governance and belonging as a way to bring out what the article proposes are key issues for assessing matters on community rights in regards to investments concerning natural resources in Africa, particularly over land. This analysis raises questions about those who uncritically promote Free and Prior Informed Consent as the solution to ensure "communities" approve any land deals.
\end{abstract}

Keywords: Land grabs, governance, Africa, community, politics of belonging

DOI:https://dx.doi.org/10.4314/jsdlp.v8i1.10

* Professor of Anthropology in the Department of Sociology and Anthropology, Carleton University, Ottawa, Canada. 


\section{INTRODUCTION}

This article will examine current scholarly and policy discussion and debate concerning investment in land in Africa and how governance is seen as a key means for ensuring increased economic value and/or greater benefits for the affected community and nation at large resulting from such economic activity. The focus in particular is on how community itself is seen as both an entity which needs to be involved in any new proposed land governance initiative as well as a presumed key beneficiary of future land investments in Africa. The article proceeds, with a brief anecdote from previous field research in Zimbabwe to illustrate some of the challenges one needs to address when thinking of how to implement such community rights in terms of land governance mechanisms. The brief anecdote concerns a proposed tourism investment in a Zimbabwean Communal Land (the postcolonial name for the former colonial "native reserves" in which the majority of Zimbabwean smallholder farmers live and farm) adjacent to a national park in the early 1990s.

The negotiations between the Hurungwe District Council, ${ }^{1}$ the then local governmental authority, and the investor based in Harare yielded an economic plan concerning a commercial intervention in the African smallholders' land area, which seemed a win-win situation. On the one hand, they had agreed for a Harare-based tourist company to offer exclusive low-impact visits of both wildlife and traditional African villages for high-paying international tourists. In turn, the villagers in the Chundu area living on the edge of Mana Pools National Park in the north-northwest corner of Zimbabwe would receive a proportion of the fees paid by the company through the administrative architecture of CAMPFIRE (Communal Areas Management Programme for Indigenous Resources), ${ }^{2}$ the then highly-regarded and widely touted

1 Since the mid-1990s the rural local authorities in Zimbabwe are called Rural District Councils.

2 CAMPFIRE is a Zimbabwean governmental programme which began in 1989 with support from the World Wide Fund for Nature (WWF), a Zimbabwe nongovernmental organization (Zimbabwe Trust), and the University of Zimbabwe's Centre for Applied Social Sciences. As its website notes, "The programme is principally designed to promote the sustainable utilization of natural resources and preserving the rich natural heritage of Zimbabwe, through the generation of income for rural communities. CAMPFIRE operates with the support of the Zimbabwe Parks and Wildlife Management Authority, as part of its conservation function in rural areas, in which 58 out of 60 Rural District Councils (RDCs) in Zimbabwe participate." Campfire Association Zimbabwe, "About Campfire Association \& FAQs" (n.d.) < campfirezimbabwe.org/index.php?option=com content\&view $=$ article\&id $=46 \&$ Itemid $=53>$ accessed 20 January 2016 . 
community-based conservation programme.

As it was explained to me by the then Hurungwe District CAMPFIRE coordinator in 1993, it seemed CAMPFIRE was a perfect vehicle for ensuring that community benefits would emerge from the then quite profitable tourist industry in Zimbabwe as it would allow the community to receive money for development initiatives as a form of compensation for the costs of living with wildlife (such as destroyed crops, occasional attacks on their domestic animals, etc.) and as an incentive so they would see economic value to wildlife and seek to conserve, not kill or poach, the wild animals. It was an investment that would fit the criteria of socially responsible investment.

Yet, a few years later the low-impact tourism business never came to fruition, regardless of it being seen as a type of socially responsible investment. Rather, the CAMPFIRE programme in this part of Hurungwe District was a heated site of struggle between the Rural District Council (the local government authority) and traditional authorities, smallholder farmers and some of their political representatives over the issue of access to land in this section of the communal land. The dispute was not only over questions about who decided which land was to be taken away from farmers to be given to wildlife but, more importantly, who decided who could gain access to the land as resident householders. In other words, the investment foundered because of a dispute of who defined the relevant community.

An important background to this initiative was that the Rural District Council officials had declared that they had legislative powers to decide who could be a resident in the Communal Lands, which is officially vested in the President and gives the local government bodies authority over them. In practice, however, access to land is largely governed by what is called communal tenure. The term can lead to assumptions that land access follows pre-colonial traditions but, as many have shown, access to land in Zimbabwe has been strongly shaped by colonial and postcolonial realities. ${ }^{3}$ In practice, communal tenure largely refers to usufruct rights for families who either have long ties to the chiefs or headman or other designated traditional authorities or who have received a piece of land from such a leader in a particular

3 Angela Cheater, "The Ideology of Communal Land Tenure in Zimbabwe: Mythogenesis Enacted?" (1990) 60, Africa,188-206; see also Donald S. Moore, Suffering for Territory: Race, Place, and Power in Zimbabwe (Duke University Press, 2005). 
Communal Land. There can be tension between these land-giving authorities and the Rural District Council who by law have the ultimate say over the distribution of land in the Communal Lands.

The local government officials saw Chundu as full of squatters, people who were not authorized to live and farm there. These officials saw CAMPFIRE as another tool to evict these squatters and to ensure that they did not receive any monetary benefits. In turn, traditional authorities assumed they had the right to allocate land to newcomers, regardless of what the government legislation and policies declared, and they resented this infringement of their authority. ${ }^{4}$ Many such newcomers in this part of the Communal Lands were former mineworkers or farm workers who came from neighbouring countries during the colonial period, or their descendants. Despite their longevity or even being born in the country to foreign parents, they are defined through citizenship laws and often in everyday practices as "aliens," and thus they often have difficulty making claims to land or resources unless they are able to find a traditional authority willing, often for a fee, to grant them access. ${ }^{5}$

4 Eric Matingo, "Projects Spark Land Use War," Horizon (Harare, Zimbabwe, July 1994), 22 <www.postcolonialweb.org/zimbabwe/politics/wildlife.html> accessed 10 October 2014.

5 See Blair Rutherford, "Conditional Belonging: Farm Workers and the Cultural Politics of Recognition in Zimbabwe" (2008), 39, Development and Change, 73-99. Fifteen years later, in 2009 there appears to be another dispute over who had the authority over granting access to land in this same area, though this time between the acting Chief Chundu and many of the villagers. The dispute was over the reported plan of acting Chief Chundu to turn over a proportion of the smallholders' land for a joint venture with a Chinese company in a wildlife safari project. In the newspaper report, at least, the Rural District Council is taking the side of the smallholders. This same acting Chief was also threatening to remove "foreigners" who he said received land from some of the headmen illegally, without registering through the local government; thus taking the perspective being put forth by the local government authority in the 1990s. Here the traditional authorities - the (acting) Chief and his headmen - were divided. See Zimbabwe Online Press," Villages to give way to game park" (Zimbabwe Online Press, 13 August 2009) <www.zimbabweonlinepress.com/ top_news/994-villagers-to-give-way-to-game-park.html > accessed12 October 2014; NewsdzeZimbabwe," Hurungwe Chief drives out "foreigners"” (NewsdzeZimbabwe, 13 August 2012) <www.newsdzezimbabwe.co. uk/2012/ 08/hurungwe-chief-drives-out-foreigners.html> accessed 10 October 2014. 
This brief example is not unique, as the academic literature concerning the implementation of CAMPFIRE critically shows how what sounded like a progressive community-based and profitable conservational initiative often ran aground on issues of who had the decision-making power over territory and who belonged there. ${ }^{6}$ This is a real life occurrence on how governance over natural resources such as land in Africa inherently raises questions not only about community rights but also about the definition of the community itself. The unproblematic community discussed with me by the Hurungwe District CAMPFIRE coordinator (and often by the promoters of CAMPFIRE and other such community-based conservation efforts) did not address the dispute between the chief and the local government authority over who was able to constitute the "community" itself.

Many commentators and analysts have recognized questions about governance as being a key factor in understanding and assessing socioeconomic consequences among the communities for the land deals, investment initiatives which have been accelerating on the continent over the last decade and longer. ${ }^{7}$ However, there is less attention to how these structures of authority and power are also involved in defining who belongs, or who has claims to belong, to these territories. As much as governance, questions of belonging also have significant impacts on land investments and the calculations of their costs and benefits.

This article explores the topic of land deals and community rights through the conceptual lens of governance and belonging, the ability to be recognized as part of the community at various levels of action (including in terms of national citizenship). I will start by briefly talking about this recent increase in land investments in Africa, setting out its

6 See Jocelyn Alexander and JoAnn McGregor, "Wildlife and Politics: CAMPFIRE in Zimbabwe" (2000) 31, Development and Change, 605-627; Vupenyu Dzingirai, "'CAMPFIRE is not for Ndebele Migrants': The impact of excluding outsiders from CAMPFIRE in the Zambezi Valley, Zimbabwe" (2003) 29, Journal of Southern African Studies, 445-459; James Murombedzi, "Devolution and stewardship in Zimbabwe's CAMPFIRE programme" (1999) 11, International Development, 287293.

7 See, for example, Hany Besada, Doing Business in Fragile States: The private sector, natural resources and conflict in Africa (2013) (Background research Paper submitted to the High Level Panel on the Post-2015 Development Agenda, May) (on file with author); Lorenzo Cotula, The Great African Land Grab? Agricultural Investments and the Global Food System (Zed Books, 2013). 
broad parameters, including public criticisms raised and some of the protests around them, and noting some of the key issues on which scholars have focused. In the next two sections, I will provide a more thorough examination of governance and belonging as a way to bring out what I argue are key issues for assessing matters on community rights in regard to investments concerning natural resources in Africa, particularly over land, which should be taken into account to help ensure there is less conflict and perhaps broader and positive development consequences for those who live there. Such issues, I will suggest, are potentially relevant for future policies concerning governance initiatives over land and natural resources more broadly in Africa.

\section{LAND INVESTMENT VERSUS LAND GRABS}

Since 2000, Africa has increasingly been a region of interest for land investment by companies, investment funds, governments, and national elites due to a confluence of wider economic pressures, policy openings, environmental changes, and political conditions. Let me give two brief examples of these dynamics. One important pressure is the growing anxieties over food security connected to rising food prices associated in part with environmental changes resulting from climate change and rising urban populations, which has made agricultural projects an attractive investment for many investors. For instance, the population of Gulf states is expected to double between 2000 and 2030, while their cereal production is projected to decline due to environmental changes, which has led many of their state agencies to invest in food production abroad. ${ }^{8}$ Another example is the 2009 European Union (EU) legislation, which requires 20 per cent of all energy used in the EU and 10 per cent of each member's state transport fuel must come from renewable sources by 2020. This has led to significant European investment into biofuel projects in Africa and elsewhere. ${ }^{9}$ Yet, at the

8 Shepard Daniel "Land Grabbing and Potential Implications for World Food Security”'in M. Behnassi, S. Shahid, and J. D. 'Silva (eds), Sustainable Agricultural Development (Springer, 2011).

9 Tinyade Kachika, T. Land Grabbing in Africa: A Review of the Impacts and Possible Policy Responses (Oxfam International, 2010) 18 <www.oxfamblogs.org/ eastafrica/wp-content/uploads/2010/11/Land-Grabbing-in-Africa.-Final.pdf > accessed 20 January 2016. 
same time, nationals acquired much of the overall land accumulation, driven by dynamics of capital accumulation and social differentiation. ${ }^{10}$

The exact amount of land transferred is disputed, depending on the methodologies used and due to often poor, public recordkeeping concerning the transfer of land in many African countries. The estimates range from 21 million to 56 or more million hectares of land acquired for investment purposes in sub-Saharan Africa during this period. ${ }^{11}$ For example, a World Bank study found that between 2004 and 2008, the amount of land transferred to investors in some African countries was very high: 4 million ha in Sudan, 2.7 million ha in Mozambique and 1.2 million ha in Ethiopia. The majority of the investors, the study observed, were nationals. ${ }^{12}$

Despite the methodological differences and disputes in interpretations, all commentators agree that Africa has been the site of growing interest in land acquisition, be it for agricultural projects for food crops or biofuels, forestry, carbon credits, or speculation, particularly after the 2008 financial crisis. For instance, Deininger and Byerlee ${ }^{13}$ note that whereas before 2008 an annual expansion of new agricultural lands on the global scale averaged about 4 million hectares, 56 million hectares of large-scale farmland deals were announced in 2009, over 70 per cent of which were in Africa. The investors tend to be a mix of companies and individuals from the particular African country, those from the country's diaspora population, other African countries (particularly South Africa), Europe, North America, Middle Eastern and Asian companies or government investors. For example, when I examined the records of approximately half of the land deals in Africa since 2000 listed on the Land Matrix in October 2014, ${ }^{14}$ in ascending order of geographical location, more secondary investors came from

10 Cotula, 52-56 (n 7).

11 See Laura German, George Schoneveld and Esther Mwangi, "Contemporary Processes of Large-Scale Land Acquisition in Sub-Saharan Africa: Legal Deficiency or Elite Capture of the Rule of Law?" (2013) 48, World Development, 1-18; Martina Locher and Emmanuel Sulle," Challenges and methodological flaws in reporting the global land rush: Observations from Tanzania" (2014) 41, Journal of Peasant Studies, 569-592.

12. Klaus Deiningerand Derek ByerleeRising Global Interest in Farmland: Can it yield sustainable and equitable benefits? (World Bank, 2011), xxxii.

13 ibid xiv.

14 Available at <landmatrix.org > accessed August 2016. 
Europe, then Asia, Africa, North America, the Middle East, and finally South America and Australia. ${ }^{15}$

The characterization and analyses of these land investment deals tend to split into two contrasting narratives of those who promote and celebrate them compared to those who decry, if not, condemn them. These two narratives dominate the media coverage of land investments in Africa and much of the scholarship. The promoters of these investments tend not only to forecast profits but they also predict positive consequences for the local community and the nation at large. Such reported and promoted benefits could include more jobs, increased demand for various services and products by local producers, higher tax revenues, and more profitable use of the land. A 2009 Food and Agricultural Organization (FAO) policy brief provides such a sanguine view. It says:

The sale of farmland to international investors is not without risks for developing countries .... They also promise several opportunities, including a technology transfer to stimulate innovation and productivity increases; quality improvements; employment creation; backward and forward linkages and multiplier effects through local sourcing of labour and other inputs. Even an increase in food supplies for the domestic market and for export is possible. However, these benefits will not come automatically, and it will take efforts of both investors and recipients of investments to realize the full potential of land deals. Above all, it requires an understanding that collaboration promises mutual benefits. ${ }^{16}$

In contrast, motivated in part by widely mass-mediated reported stories about proverbial sweetheart deals on land investment, where investors were given preferential and undervalued access to land compared to local peoples, and a historically grounded scepticism of outside investors promising betterment for (rural) Africans, there has been a strong critique of these land investments, characterizing them

15 See also Cotula (n 7).

16 FAO (Food and Agricultural Organization), "From Land grab to Win-Win: Seizing the Opportunities of International Investments in Agriculture" (Economic and Social Perspectives Policy Brief 4, June 2009). 
as an African land grab. ${ }^{17}$ From reporters to activists to academics in and outside of Africa, there have been numerous concerns raised about these so-named land grabs, including the displacement of existing populations and removing land-based resources from their use, which undermine food security and other local livelihoods and cause other detrimental environmental, social and political consequences. This perspective criticizes the investors and the African governments, who facilitate such investments, for not putting the interests of the local rural African farmers, pastoralists, and fishers first. As laid out by The Oakland Institute in a series of investigative reports, "large scale investments in land in Africa are resulting in food insecurity, the displacement of small farmers, conflict, environmental devastation, water loss, and the further impoverishment and political instability of African nations." 18

For instance, in Tanzania and Ghana after land was taken for jatropha plantations by foreign investors and the actual investments fizzled out, there were reports about how those local populations made landless by the plantations or had their landscapes transformed by the investment were in much poorer economic shape than before the investment. ${ }^{19}$ Also, as noted in Footnote 17, a controversial land investment by Daewoo in Madagascar became a reason for greater

17 One of the most prominent cases involved a South Korean investment in Madagascar. The 2008 Financial Times report of the South Korean conglomerate Daewoo's 99 year lease of 1.2 million hectares in Madagascar to grow maize and palm oil, largely for the South Korean market, with the company's expectation they would not pay anything for the land, is widely recognized as helping to set off the a wave of stories of the "African land-grab." S. Jung-a, C. Oliver and T. Burgis, "Daewoo to cultivate Madagascar land for free" Financial Times (London, 20 November, 2008) <www.ft.com/cms/s/0/6e894c6a-b65c11dd-89dd-0000779fd18c.html\#axzz3HdUoAk00> accessed 29 October 2014. See also Barry Ness, Sara Brogaard, Stefan Anderberg, and Lennart Olsson," The African Land-Grab: Creating Equitable Governance Strategies through Codes-of-Conduct and Certification Schemes" (2009) Conference on the Human Dimension of Global Environmental change. Amsterdam, 2-4 December < www.earthsystemgovernance.org/ac2009/papers/AC20090294.pdf $>$ accessed 5 November 2014.

18 Oakland Institute. "Special Investigation Phase One: Understanding Land Investment Deals in Africa" (Oakland Institute, n.d.) < media.oaklandinstitute. org/special-investigation-understanding-land-investment-deals-africa $>$ accessed 14 October 2014.

19 Cotula, 141, 143 (n 7). 
protests. Recent protests in Ethiopia, in which the state cracked down on and killed more than 100 people, were also tied up with the government's plan to expand the capital of Addis Ababa. Many people in the surrounding communities and others saw this plan as a way for the state to grab land from them, ${ }^{20}$ an action that the Ethiopian government has done elsewhere, displacing tens of thousands if not more. $^{21}$

Although the narratives promoting land investment in Africa and those that criticize them as land grabs are polar extremes in terms of assessing consequences of this growing trend, they tend to converge when suggesting how they can be improved. The convergence centres on governance. The promoters of land investments and the detractors argue that better governance can ensure the distribution of development benefits or ensure that those affected by the land deals have a voice in terms of agreeing to them and in negotiating particular benefits for themselves.

An example is the FAO document cited earlier. It lists issues which investors and policy-makers should examine to ensure that the collaboration between investors and recipients of investment lead to mutual benefits such as better systems to recognize local land rights, imposition of labour, social and environmental standards, ${ }^{22}$ stakeholder involvement and codes of conduct and other more inclusive strategies. ${ }^{23}$ In turn, the critics of land grabs point to the lack of accountable governments in Africa which enable these deals to take place; deals

20 Mathias Mundi, "Why Ethiopia is making a historic "master plan" U-turn" (BBC Monitoring, 18 January 2016) <www.bbc.com/news/world-africa-35325536> accessed 20 January, 2016.

21 Human Rights Watch, "Waiting Here for Death": Forced Displacement and "Villagization" in Ethiopia's Gambella Region (Human Rights Watch, 2012).

22 Such standards have become common goals promoted by many international agencies, including international financial institutions. For instance, in 2006 the International Financial Corporation and the Multilateral Investment Guarantee Agency of the World Bank Group revised the performance standards required by those companies receiving loans to focus on social, environmental and labour standards and broader community impacts. The aim is to "minimize commercial and reputational risks caused by loopholes in legislation or enforcement capacity in countries where investments are implemented." Deininger and Byerlee, 136 (n12).

23 FAO, 2 (n 16). 
which turn out to be largely detrimental to African smallholder farmers, pastoralists and fishers. ${ }^{24}$

Governance has thus become the lodestone for policy analyses and scholarly attention to land investments in Africa: it carries the burden to try to improve the existing situation to ensure that future land deals are less contentious and can lead to equitable economic growth. Land governance has become a dominant area of mainstream policy concern in terms of finding efficient and effective ways of administrating land issues through, for example land titles, cadastres, decentralization and so forth. ${ }^{25}$ Observably, with regards to the topic of large-scale land investments, the term has also taken on more democratizing agendas of providing additional public information about the deals and better consultation mechanisms and decision-making processes which, it is argued, ensure those local communities who are affected by the transfer of access to land have a voice and a say in the deals.

\section{LAND GOVERNANCE: PINNING DOWN THE COMMUNITY}

There are a series of global, regional and national land governance initiatives seeking to guide or regulate investments in agriculture. ${ }^{26}$ A key element in these initiatives is the importance of some form of community involvement in the proposed governance schemes. The FAO's "Voluntary Guidelines on the Responsible Governance of Tenure of Land, Fisheries and Forests in the Context of National Food Security" 27 provide guidance to governments for the development of national level policies and programmes to try to ensure that more

24 Oakland Institute, "Understanding land investment deals in Africa" (Oakland Institute, December 2011) <www.oaklandinstitute.org/sites/oakland institute.org/files/OI_brief_land_grabs_leave_africa_thirsty_1.pdf $>$ accessed 22 October 2014.

25 Saturnino Borras Jr. and Jennifer Franco, "Contemporary Discourses and Contestation around Pro-Poor Land Policies and Land Governance" (2010) 10 Journal of Agrarian Change, 2.

26 German, Schoneveld and Mwangi, 3 (n 11).

27 FAO, Voluntary Guidelines on the Responsible Governance of Tenure of Land, Fisheries and forests in the Context of National Food Security (FAO, 2012). See also African Union, Economic Commission for Africa and the African Development Bank Consortium, Framework and Guidelines on Land Policy in Africa. Addis Ababa: AUC-ECA-AfDB Consortium (African Union, 2010). 
sustainable and transparent land governance systems emerge, including the role of indigenous land institutions (also known as customary tenure institutions). There is no scholarly evidence of which I am aware that shows how it has been implemented. Nonetheless, there are high hopes that the guidelines will make state governance regimes over natural resources more responsive to communities, particularly since many of the voluntary guidelines explicitly refer to existing human rights obligations in regards to natural resources. ${ }^{28}$

Other initiatives focus specifically on advocating for better governance of land investment. For example, the FAO, International Fund for Agricultural Development, the United Nations Conference on Trade and Development and the World Bank set out the "Principles for Responsible Agricultural Investment that Respects Rights, Livelihoods and Resources". ${ }^{29}$ In turn, the UN Special Rapporteur on the Right to Food provides guidelines to investors and host countries on securing human rights in the context of large-scale land acquisitions and leases. ${ }^{30}$

Almost all commentators agree that the governments of specific African countries are the key agency to be reformed. ${ }^{31}$ In particular, analysts argue that African governments need to implement better land governance, which can guarantee transparency, inclusive decisionmaking, and take into account community rights. For example, as some

28 Philip Seufert, "The FAO Voluntary Guidelines on the Responsible Governance of Tenure of Land, Fisheries and Forests" (2013) 10, Globalizations, 181-186.

29 FAO, International Fund for Agricultural Development, the United Nations Conference on Trade and Development and the World Bank "Principles for Responsible Agricultural Investment that Respects Rights, Livelihoods and Resources. A discussion note" (25 January 2010) < siteresources.worldbank. org/INTARD/214574-1111138388661/22453321/Principles_Extended. pdf $>$ accessed 14 October, 2014.

30 Olivier De Schutter, "Large-scale land acquisitions and leases: A set of core principles and measures to address the human rights challenge" (11 June 2009) < www2.ohchr.org/english/issues/food/docs/BriefingNoteland grab.pdf $>$ accessed 16 October, 2014. See also United Nations Human Rights (Office of the Commissioner), "Vulnerable land users must be protected by international guidelines - UN expert urges Rome summit" (UNHR Press Release, 3 October 2011) <www.srfood.org/images/stories/pdf/press_releases/ 20111003 _pr_vg.pdf $>$ accessed 22 October 2014.

31 Liz Alden Wily, "The Law is to Blame: The Vulnerable Status of common Property Rights in Sub-Saharan Africa" (2011) 42, Development and Change, 733-757; Lorenzo Cotula, Sonja Vermeulen, Paul Mathieu and Camilla Toulmin", Agricultural investment and international land deals: Evidence from a multicountry study in Africa" (2011) 3, Food Security 3, S99-S113. 
authors put it, "The central role of host governments in allocating land raises a number of issues, particularly with regard to the extent to which these governments take account of local interests in land, water and other natural resources." ${ }^{2}$ Local interests speak to the issue of community rights and how to ensure they are taken into consideration in the land governance systems, particularly when land is alienated for sale or lease to foreign and national investors.

To better understand the issue of community rights and land governance, a number of studies have focused on the problematic relationship between national laws and institutions and what can be called customary land tenure. In an important and widely recognized contribution, Liz Alden Wily ${ }^{33}$ proposes that over half the land base in sub-Saharan Africa is governed by customary norms, involving around half a billion landholders.

After independence, as she points out, many postcolonial African states continued colonial-era policies and laws which vested the ownership of untitled lands or lands held under customary regimes in the state. This means that even though land allocation, use, and adjudication may be done largely through the rules, practices and institutions which could be called customary tenure, legally the state or some state body actually owns the land, as is the case in Zimbabwe as the introductory example shows.

Most of the lands targeted in this land rush can be found in common property regimes; hence they are regarded as public lands. A great deal of these lands is legally owned by the state and many government authorities see foreign investment as a way to expand the economy and modernize what they deem to be unproductive utilization of the land. ${ }^{34}$ Continuing the colonial discourse which devalued African agricultural practices, ${ }^{35}$ government officials argue that foreign investors will improve agricultural production and the national economy compared to existing land uses; an argument which has helped the dispossession of many Africans, not necessarily with compensation, in order to transfer the land to the land investors.

32 Cotula, Vermeulen, Mathieu and Toulmin, S104 (n 31).

33 Alden Wily, 735 (n 31).

34 Kachika, 8-9 (n 9).

35 See Donald S. Moore, "The Crucible of Cultural Politics: Reworking "Development" in Zimbabwe's Eastern Highlands (1999) 26, American Ethnologist, 654-689. 
Even though rights-based initiatives and pressures over the last twenty years have influenced greater attempts to democratize legislation concerning land administration, the empirical record suggests these actions have been limited in practice, if not in design. Alden Wily ${ }^{36}$ herself critically reviews the different land laws in a number of sub-Saharan African countries and shows their limitations in terms of recognizing any sort of community rights in regards to dispossession. The key criterion she deploys in pointing out the weaknesses of legislation is the lack of democratic institutions to enable land users to participate in the negotiations with investors, and the ability to give or withhold consent.

Alden Wily shows that the laws in the majority of African countries define such land as state or public land to be disposed of at the discretion of the government with no consultation of the local landholders: "While other, largely governance enablers pave the way to dispossession, the most efficacious is the law; that is, the terms by which legislation in so many [sub-Saharan African] economies renders unregistered, untitled lands and/or lands acquired and held under indigenous or customary regimes, the property of the state." ${ }^{37}$ Accordingly, through this evaluative lens she clearly finds these laws to be discriminatory. But even those countries which acknowledge communal rights are found wanting under her examination.

While she argues that her critical assessment shows the need to institute more rights-based changes to legislation and policies (an argument clearly laid out in the title of her article, "The law is to blame"), others suggest that even if such changes were to occur they may not be sufficient to change the power imbalance. For example, Laura German, George Schoneveld, and Esther Mwangi ${ }^{38}$ carefully review the legislation and policies concerning land tenure and acquisition, investment promotion and environmental protection as well as stakeholder experiences with land acquisition in Ghana, Mozambique, Tanzania and Zambia. They found that despite great variation in legal frameworks governing large-scale land acquisition in the four countries, there was the same result: a loss of customary rights to vast areas of land.

German, Schoneveld, and Mwangi ${ }^{39}$ also underscored weaknesses

36 Alden Wily (n 31).

37 Alden Wily, 740 (n 31).

38 German, Schoneveld and Mwangi (n 11).

39 Ibid. 
in legislation, policies and institutional arrangements governing customary land rights and their transfer to others. Contrary to Alden Wiley's the-law-is-to-blame argument, the former suggests that the law is not the only source of problems. Rather, they stress the role of human agency in influencing outcomes that are detrimental to local communities. To bolster their argument, they present examples such as motivations of personal enrichment of chiefs; the strong faith in the modernization narrative and large-scale government investment which makes them discriminate against what they perceive as traditional and backward communal land uses; the widespread incentive for officials in local government and line ministries to generate revenue, which make them predisposed to look for ways to generate rents rather than, say, turn down land investment opportunities; differential awareness and expectations amongst community members vis-à-vis their land rights and what they would receive from land investment; and the difficulty of customary land users to question the authority of local and customary leaders, whether due to custom, intimidation, coercion by outsider actors, or legal illiteracy. ${ }^{40}$

Recognizing such power relations, forms of accumulation, and potential for elite capture arguably motivated Klaus Deininger, the lead economist for the World Bank's Development Research Group, to propose ambitious interventions which would use participatory tools to enable land registration that "reflect local perceptions of existing rights" and to establish local bodies which are accountable and representative to administer them. His initiative would allow for:

community management of basic land administration processes (such as allocation of individual rights, updating of registries, and other internal affairs, according to given bylaws); boundaries are recorded and a clear internal governance structure (with internal control structures) is established to allow interaction with outsiders; records are integrated with those used in the regular land administration system to prevent double-allocation of land, to allow land users enter into joint ventures with investors, or to allow groups to gradually individualize land rights if desired; and relevant secondary rights, including use rights to land and associated natural resources, such as those held by pastoralists, migrants, and forest dwellers, are recorded and protected, rather

40 Ibid, 15. 
than eliminated or ignored, e.g. by documenting them in land use plans that identify cattle tracks, seasonal grazing areas, and watering sources .... To prevent [local elites using this process for their own benefit] ..., structures are needed to make decisions about such rights in a way that is understood locally and represented the interests of all rights holders. ${ }^{41}$

This all-encompassing initiative would theoretically help ensure that democratic governance is instituted. It also would enable Free, Prior and Informed Consent (FPIC) of the land users before the leasing or alienation of land. The many years of agitation and advocacy has increasingly made this a key criterion for many development agencies, including the World Bank Group, as a way to minimize conflicts over large-scale investments. ${ }^{42}$

Land activists and those critical of large-scale land investments have also taken up this legal technique, which is basically a contract between the investor (or new land holder) and existing land users. ${ }^{43}$ Since the 1990s, FPIC has been used to provide extensive information on the project, potential risks, benefits and alternatives to the proposed intervention to all stakeholders and to seek the approval of those most affected. ${ }^{44}$ It has become a means of trying to ensure that local landholders and land users provide their consent free of any coercion and based on the provision of full information; although some acknowledge it is difficult to do so as most such local groups often are socially divided entities. ${ }^{45}$ It is this point, I suggest, that needs to be explored further if something like community rights will be actualized in new governance arrangements over land.

Such difficulties are apparent in the above quotation from Deininger, which comes across as slightly fantastical, divorced from the politics and the social relations shaping governance and authority throughout

41 Klaus Deininger, "Challenges posed by the new wave of farmland investment" (2011) 38, Journal of Peasant Studies, 237.

42 Brant McGee, "The Community Referendum: Participatory Democracy and the Right to Free, Prior and Informed Consent to Development" (2009) 27, Berkeley Journal of International Law, 570-635.

43 See, for example, Ward Answeeuw, Liz Alden Wily, Lorenzo Cotula, and Michael Taylor, Land Rights and the Rush for Land: Findings of the Global Commercial Pressures on Land Research Project (International Land Coalition, 2012).

44 Robert Goodland, "Free, Prior and Informed Consent and the World Bank Group" (2004) 4, Sustainable Development Law and Policy, 66-74.

45 See also Cotula, 189 (n 7). 
rural Africa. In the passage cited above, rural African communities appear as if they could easily be transformed to become well-functioning bureaucratic entities, which obey radically democratic decision-making procedures.

In the remainder of the article, I will problematize the assumption that smallholder farmers form an undifferentiated community based on co-residence and would welcome such thoroughly democratized administrative and representative structures as Deininger presents. Instead of assuming that the current range of overlapping authorities over the people in these land areas would even be keen to initiate such a transformative programme and to support it, I propose that it is more productive to understand how governance occurs on the ground and to examine what possibilities exist, if any, for promoting something like community rights in the context of land transfers. The cultural politics of belonging is a key dimension of authority and decisionmaking mechanism over land in Africa, which needs to be taken seriously in light of efforts to promote some sort of community rights.

\section{THE CULTURAL POLITICS OF BELONGING}

While there is increasing recognition in international policy instruments and scholarship, as well as advocacy to have some form of community representation in regards to decisions made concerning land deals, what that means and how to achieve it are not straightforward. This section examines the tricky issue of conceptualizing community in regards to land and how this can make it difficult to ensure its realization given the typical varied interests and claims to a territory, which may overlap with others, in any type of FPIC initiative.

Most authors acknowledge that rural communities in Africa are not homogenous but have a range of social differentiation along many social axes such as gender, class, ethnicity, kinship, etc. Nonetheless, some authors hold out for the possibility of constructing democratic governance mechanisms, which could effectively represent these differentiated communities. ${ }^{46}$ Others suggest that it is unlikely to ever have any defined community give up its access to a valuable resource like land, thereby questioning "the assumption that identified

46 See Cotula (n 7). 
infringements on customary rights and rural livelihoods will disappear through additional legal and governance reforms." ${ }^{47}$

Rather than necessarily assuming either avenue is correct (that a more democratic governance mechanism can be constructed or that further governance reforms will not convince rural land users to give up their land), I suggest that one needs to examine the configuration of power and authority relations, that is, what Bonnie Campbell has termed modes of governance. ${ }^{48}$ Recalling at the same time how governance dynamics shape people's access to land as a focal lens on possible ways to ensuring that more broad-based community rights may be established and enforced in land deals. Modes of governance over land brings together different authorities of varying scales of action (e.g., national, district, local) and helps to constitute different subjects with differential claims and rights towards various natural resources (such as land, minerals, water, trees, and so on). In other words, the meaning of community itself in relation to rural Africa is intimately connected to the forms of governance over land.

The national state is a crucial player, as its laws and policies inform who should have access to certain categories of land and its transfer. In regards to territories designated for customary tenure, its rules often define who can gain access to land and who are the main land-giving authorities (such as chiefs, clan leaders, district governments, and so on). These help to define the outlines of the community, but they are typically fleshed out in more detail by the actual land-giving authorities. These land-giving authorities are both the state-sanctioned ones and those who may have complementary or competing authority, based on other legislation or other moral orderings constituting twilight institutions operating in the shadow of the state. ${ }^{49}$

It is at the level of the actual land-giving authorities that one sees the interconnections between community formation and land. These land-giving authorities decide who gains access to land and how it is transferred. The criteria for getting land usually helps to define how one belongs or not to some sense of community with particular rights for accessing one's own land and for accessing common property. Such

47 German, Schoneveld and Mwangi, 15 (n 11).

48 Bonnie Campbell (ed), Modes of Governance and Revenue Flows of African Mining (Palgrave Macmillan, 2013).

49 Christian Lund, "Twilight Institutions: Public authority and local politics in Africa" (2006) 37, Development and Change, 685-705. 
criteria are often along the lines of lineage, generation, clan or ethnicity and are gendered (almost always favouring men as the main landholders). These criteria create "insiders" and "outsiders" as "rights to land are closely connected to belonging to certain communities; however, belonging is contested, negotiated, and made". ${ }^{50}$

One fault-line for the contestation and negotiation of belonging comes from the land rights given to those whose claims are disputable. For example, different land-giving authorities may allow those who are deemed to be strangers from the normative contours of the community to gain access to land either as primary landholders or secondary land users in some sort of leaseholder arrangement; as discussed below on the tutorat institution in Côte d'Ivoire. Others may even purchase land on a small scale, even if there is not a formal land market, through what Chimhowu and Woodhouse $(2006)^{51}$ term "vernacular land markets". The latter refers to the fact that in legal prohibitions against the sale and purchase of land in places like Zimbabwe's Communal Lands, there exists a form of informal purchasing and selling of pieces of land. In the case of Zimbabwe, this practice has increased in the Communal Lands.

There may be various forms of incorporation for these individuals or their children to be considered as belonging to a community in whose territory they live (such as marriage, participating in community activities, recognizing ritual activities and prohibitions concerning the land, etc.). It is at the same time common for such people and their descendants to be considered strangers, even after several generations.

During times of crises, the differential axes of rights and access to land can become fault-lines for conflict. In the last few decades, we have seen these competing claims or divisions flaring up into serious, if not violent disputes, often amplified by changing economic conditions and political circumstances, with these land disputes contributing to

50 Jorg Gertel, Sandra Calkins and Richard Rottenberg, "Disrupting Territories: Commodification and its Consequences." In J. Gertel, R. Rottenberg and S. Calkins(eds), Disrupting Territories: Land, Commodification and Conflict in Sudan (James Currey 2014), 10. See also Richard Kubaand Carola Lentz (eds), Land and Politics of Belonging in West Africa (Brill, 2006) and Rutherford (n 5).

51 Admos Chimhowu and Phil Woodhouse "Customary vs Private Property Rights? Dynamics and Trajectories of Vernacular Land Markets in Sub-Saharan Africa" (2006) 6, Journal of Agrarian Change, 346-371. 
both. Examples include Côte d'Ivoire, ${ }^{52}$ eastern Democratic Republic of Congo, ${ }^{53}$ and Sudan. ${ }^{54}$ In each of these countries, there are instances of overlapping claims to the same land by different individuals and groups, asserting that they represent particular communities who have a right to the land. In other instances, there can be generational and gender differences in terms of decisions made to lease out land.

For example, as explained by Jean-Pierre Chauveau, ${ }^{55}$ in Côte d'Ivoire (and elsewhere in West Africa), one can find an institution of tutorat, which is an arrangement in which migrants are able to secure access to land in areas of which they are strangers. The resident families who give land on loan or sale to the migrant uses this institution to ensure that the recipient is indebted to the land giver. This debt takes various forms but usually a symbolic payment upon receipt of the land or an annual share of the crops or an expectation of financial support during times of crises. This hierarchical relationship continues through the generations between land lenders/sellers and land recipients. This institution was particularly popular from the 1950s to1970s when the colonial and postcolonial governments encouraged migration of farmers or labourers to the cocoa-growing regions. Notably, when the national economy began to have great difficulties in the 1980s, there became growing pressure to renegotiate these arrangements, particularly by sons of the land-giving families who had migrated to urban areas. As their economic prospects dimmed in the cities, they were worried about the ability to access land in their home areas because, they argued, much of it had already been allocated to "foreigners" over the decades. This sentiment was reinforced and in turn intensified wider political movements over who properly belonged to the nation, leading ultimately to violent conflict.

These dynamics are important to recognize, for it means that foreign investors are entering typically into already contested fields. It is important to recognize that even though African governments may

52 See Jean-Pierre Chauveau, "How Does an Institution Evolve? Land, Politics, Intergenerational Relations and the Institution of the Tutorat amongst Autochthones and Immigrants (Gban Region, Côte d'Ivoire)" in R. Kuba and C. Lentz (eds), Land and the Politics of Belonging in West Africa (Brill 2006), 213240 .

53 See Chris Huggins, Land, Power and Identity: Roots of violent conflict in Eastern $D R C$ (International Alert, 2010).

54 Gertel, Calkins and Rottenberg (n 50).

55 Chauveau (n 52). 
have the legal right to lease out land, which is being used by communities, many who live on and use the land dispute that legal right. Even if government officials or investors seek to meet community representatives, it is not always a straightforward operation to determine which community is being represented.

Nonetheless, this intensive interest by foreign and national investors in acquiring land in Africa and the backlash, criticisms and resistance it has generated means there are opportunities to develop policies which seek to improve community rights. To do so, would mean that one should seek to establish mechanisms that determine the various rights and claims to lands and to craft ways to mediate disputes between different claimants. Such efforts have been undertaken in different jurisdictions and it is a difficult and often long-term process. Notably, there could be mechanisms set up to determine land rights in areas of land which the government wishes to lease out to investors.

The key step is to determine the rights and claims to land. It would be imperative to involve a multi-stakeholder mechanism to do this work. Colonial and post-colonial history in Africa is rife with the marginalization or exclusion of different communities, women, and others through exercises which privileged the voices of a few in determining who has land rights and who does not. On the one hand, evidence shows that women have had less access to land ownership than men throughout Africa since at least the colonial period, though the reality of this claim varies considerably across countries. ${ }^{56}$ On the other hand evidence abounds of people being excluded on the basis of ethnicity or other types of social distinctions such as the difficulty many former farm workers had in receiving land in the Fast-Track Land Resettlement exercise in Zimbabwe. These men and women had lost their jobs due to the massive and often chaotic land resettlement process in Zimbabwe in which the government redistributed whiteowned commercial farms to black Zimbabweans.

Largely on the assumption that they were foreigners, following colonial labour migration patterns, many former farm workers were discriminated against in the land redistribution exercise. ${ }^{57}$ This tendency

56 Cheryl Doss et al, "Gender inequalities in ownership and control of land in Africa: Myth and reality" (2015) 46, Agricultural Economics, 403-434.

57 Evert Waeterloos and Blair Rutherford, "Land Reform in Zimbabwe: Challenges and Opportunities for Poverty Reduction Among Commercial Farm Workers" (2004) 32, World Development, 537-553. 
was challenged when the land rights determination process could not have only government officials on it but also members of the civil society organizations who work on rural development issues, representatives of different communities who use the land (by ethnic groups, generation, lineages or clans, and gender), and researchers from the country who work on land issues. I am unaware of any such empirical examples but I would think that without such a wide representation, then there is a good chance that certain land rights or claims would be ignored.

This mechanism could also determine whether or not there is land for lease and, if so, who would be compensated and by how much. This would be a difficult and contentious process and it may result in a decision that there is no land to lease out. Observably, for investors who want the greatest legitimacy within the wider communities and to ensure that their payments go to those who are losing access to land, this type of process is necessary, even if it may prove to be a long and arduous one.

One could also develop a research tool to guide research by independent, national researchers which look minimally at the various land uses, primary and secondary rights to land-based resources, and the various forms of governance and communities associated with, if not constituted through, them. Such a tool would be adapted to each situation. Its results would have to go through some sort of verification process among the various land users and authorities and presented in a way that land users can understand and posted in a transparent fashion for others to interrogate. Once verified and viewed as legitimate, the results can be used to determine those in the community or communities who need to be consulted and provide their FPIC for any transfer of land away from them and the type of compensation required.

Such processes may engender new notions of community regarding access to the land and they may also lead to further disgruntlement as these communities are fraught with different histories and politics. Furthermore, these processes are not guaranteed to work, given the contentious nature concerning access to most lands in rural Africa along with tendency towards great suspicions between various rural-based populations and the state. Nevertheless, only by seeking to be inclusive and attendant to local understandings of who has different rights to land can there be a chance of having some sort of community rights recognized during the land transfer process. 


\section{CONCLUSION}

Among some policy makers, activists and scholars, there is a growing demand for some sort of recognition of community rights as a way of ensuring that the rapid increase of land investment in Africa does not lead to displacement and further erode equitable growth opportunities. One policy tool that has been introduced is to secure the Free, Prior and Informed Consent (FPIC) of the land users before the leasing or alienation of any land.

Such recognition of community rights needs to be applauded and built upon, but the devil is in the details. This article has identified how land held in some sort of customary arrangements, which is the type of legal setting for the majority of African land users, entails a whole set of different problems. In particular, a significant problem recognized in this article is the identification of the community itself, as there is often nested land rights to most of such land and landbased resources, constituted in part through different overlapping or contested forms of governance mechanisms. Back to the CAMPFIRE example at the start, while the local government had legal rights to administer and determine who had land access in the communal lands, in practice the traditional authorities were the land-giving authorities and they could give land out to people who were deemed to be foreigners and thus legally proscribed from having land in these areas. Accordingly, identifying the particular community to ascertain the FPIC leads directly to the thorny question of who holds land rights and who decides who holds which rights from the state to the district and then local level itself.

These issues may be daunting for outsiders, let alone for many who inhabit such social webs. Where those promoting or governing land transfers want to try to minimize conflict and ensure a broader based support for these land investment deals, then they need to spend the energy and time in developing processes that can thoroughly identify and work with the various land users and land holders. Such efforts of engaging the people who live in the territory of interest could also ensure that many of them benefit from any eventual external investment in the land which occurs, in terms of employment, training, providing downstream inputs and services, and so forth. That is, by taking the task of identifying and consulting the communities as seriously as possible, the investors could become more anchored into the territory and there could then be a greater likelihood of multiplier effects. This 
would be different from being a socially thin enclave, generally separated from the economies of the people who live around them, which has become the norm for most large-scale external land-based investments in Africa (for example, mining, oil, agriculture, etc). ${ }^{58}$ Nonetheless, as shown by programmes involving investment into communally-held land, which are generally considered models of sustainable development and socially responsible such as CAMPFIRE in Zimbabwe, there are no guarantees that those laudable goals will be achieved. Indeed they can end up amplifying disputes about who are the actual land-giving authorities and who defines members of a territory.

Given the increased activist and media attention towards land grabs in Africa, aims to lease large amounts of land for various foreign-driven motives try to ensure some sort of legitimacy among many of the affected communities. If those involved in these land transactions do not recognize some of the existing, on-the-ground dynamics of authority and power - that is, the forms of governance - and their connection to the actual formation of the communities which use the land, then there is a likelihood of limited success in ensuring FPIC, let alone wider development consequences among those who live adjacent to these areas of investment. Rather, social science evidence suggests that one needs to invest in understanding these dynamics of governance and belonging as a way to ascertain whether one can move forward with, and not against, the particular communities involved in the territory identified.

58 James Ferguson, Global Shadows: Africa in the Neoliberal World Order (Duke University Press 2006), p. 38. 